\title{
Effects of different postbreeding treatments on fertility of thoroughbred mares
}

\author{
R. C. Mattos, E. Malschitzky, R. Mattos and R. M. Gregory \\ Reprolab, Departamento de Medicina Animal, Faculdade de Veterinária, Universidade Federal do Rio Grande do Sul, Brazil
}

\begin{abstract}
Summary
The purpose of this study was to determine whether the postbreeding intrauterine treatments with homologous plasma, homologous plasma with leukocytes, or homologous plasma with antibiotics improve pregnancy rates per cycle. Control mares received no treatment. Mares $(n=394)$ were assigned to different groups according to their reproductive status. All mares in each group were randomly allocated to one of the treatments. Intrauterine treatments were given 13 to 36 hours after mating. The early pregnancy rates in maiden and lactating mares were not significantly affected $(p>0,05)$. Barren mares treated with plasma plus leukocytes had higher early pregnancy rates per cycle $(p=0,047)$ than those submitted to other treatments. Thus, an intrauterine infusion of plasma and leukocytes after breeding improves pregnancy rates per cycle in barren mares.
\end{abstract}

keywords: $\quad$ mares, postbreeding therapy, plasma, leukocytes

\begin{abstract}
Effekte unterschiedlicher Behandlungsmethoden nach der Bedeckung auf die Fertilität bei Vollblutstuten
Ziel der Untersuchung war ein Vergleich unterschiedlicher intrauteriner Behandlungen nach der Bedeckung (homologes Plasma, homologes Plasma mit Leukozyten oder homologes Plasma mit Antibiotika) in Hinblick auf die Frühträchtigkeitsraten. Die Stuten ( $n=394$ ) wurden ent sprechend ihres Reproduktionsstatus eingeteilt und nach dem Zufallsprinzip einer der Therapiegruppen zugeordnet, 122 Tiere blieben unbehandelt. Die intrauterine Behandlung wurde 13-36 Stunden nach der Bedeckung durchgeführt. Die Frühträchtigkeitsrate bei Maiden und laktierenden Stuten wurde nicht beeinflußt $(p>0,05)$. Die Gruppe derjenigen güsten Stuten, die mit Plasma und Leukozyten behandelt wurden, wies eine höhere Frühträchtigkeitsrate $(p=0,047)$ verglichen mit den der anderen Behandlungsgruppen. Hieraus wird der Schluß gezogen, daß eine intrauterine Infusion mit homologen Plasma und Leukozyten nach der Bedeckung die Trächtigkeitsrate bei güsten Stuten erhöht.
\end{abstract}

Schlüsselwörter: Stute, Therapie nach der Bedeckung, Plasma, Leukozyten

\section{Introduction}

Bacterial infection of the genital tract has been recognized as an important cause of infertility in the mare (Hughes \& Loy, 1975). During breeding the uterus is frequently contaminated with bacteria (Dimmock, 1939; Kenney \& Ganjam, 1975). Following contamination, the uterus responds to the contaminant. Most mares eliminate the agent within a few hours or days (Evans et al., 1986; Watson, 1988), remaining free of infection before the embryo enters the uterine cavity.

Some evidences support the idea that fertile mares effectively eliminate bacteria from the uterus (Asbury et al., 1982). In young fertile mares the fertilization rate is about $96 \%$ (Ball et al., 1986) and the embryo recovery can reach $80 \%$ (Squires et al., 1982; Pascoe et al., 1985). However, several researchers have proposed that impaired uterine physical clearance, i. e., defective uterine contractility and lymphatic drainage, and local cellular and humoral immunity prevent some mares from eliminating contaminants. These problems characterize mares as susceptible to endometritis (Cheung et al., 1985; Evans et al., 1986; Allen \& Pycock,
1988; LeBlanc et al., 1989; Troedsson \& Liu, 1991 and 1992; Troedsson et al., 1993a, 1993b and 1995; LeBlanc et al., 1994 and 1995).

Uterine lavage with plasma, oxytocin injections and combination of both have been recommended as treatments for postbreeding endometritis (Asbury, 1986; Pascoe, 1995). In an experiment with 905 Thoroughbred mares, Pascoe (1995) observed that intrauterine infusion of homologous plasma and antibiotics (penicillin and neomycin) 12 to $36 \mathrm{~h}$ after breeding significantly improved the pregnancy rate per cycle in lactating and in barren mares. Better results were attributed to: addition of opsonines enhancing chemotaxis and PMN-phagocytosis; increased internal uterine volume and consequent dilution of uterine secretions containing toxic by-products; and addition of antibiotic that eliminates remaining bacteria.

intrauterine infusion of homologous plasma with leukocytes associated with uterine lavage is an effective method to eliminate bacteria (Castilho, 1994; Castilho et al., 1994). In experimental infections this method resulted in less days to 
bacterial elimination than either intrauterine homologous plasma infusion or intrauterine lavage with saline.

The purpose of this study was to determine whether postbreeding therapies using intrauterine homologous plasma, homologous plasma with leukocytes or homologous plasma with antibiotics improve the pregnancy rates per cycle in maiden, barren and lactating mares.

\section{Material and Methods}

This study was conducted during the breeding seasons of 1994 and 1995 in two different broodmare farms in Southern Brazil. All mares were maintained on pasture and were supplemented with grain and alfafa hay.

Mares $(n=394)$ between 3 and 23 years of age were assigned to different groups according to their reproductive status (maiden, barren and lactating ). Maiden and barren mares were examined for reproductive soundness at the onset of the first detected estrus and lactating mares at the first period after foaling. All mares were submitted to rectal palpation of the internal reproductive tract and vaginal examinations with speculum. Perineal conformation was evaluated and proper corrections performed when necessary. Endometrial biopsies (Kenney \& Doig, 1986) and cervical swabs for culture and cytologic examination (Mattos et al., 1984) were taken from barren mares.

Mares were teased daily for detection of estrus. Follicular growth control by rectal palpation and ultrasonography were performed daily and started when the first day heat was detected. Mares were bred by proven fertile stallions after detection of a preovulatory follicle (>40 mm).

Mares in each group were randomly assigned to one of the following postbreeding treatments:

T1 - Untreated controls

T2 - Plasma: Intrauterine infusion of $120 \mathrm{ml}$ homologous plasma

T3 - Plasma + Leukocytes: Intrauterine infusion of $120 \mathrm{ml}$ homologous plasma with leukocytes

T4 - Plasma + Antibiotics: Intrauterine infusion of $120 \mathrm{ml}$ homologous plasma with $5 \times 10^{6} \mathrm{IU}$ procaine penicillin and $2 \mathrm{~g}$ streptomycin sulfate.

Tab. 1: Pregnancy rate at day 14 in Thoroughbred barren mares after different postbreeding treatments.

Trächtigkeitsrate am Tag 14 bei güsten Vollblutstuten bei unterschiedlichen, nach der Bedeckung durchgeführten Behandlungen.

\begin{tabular}{|lll|}
\hline Treatments & \multicolumn{2}{l|}{$\begin{array}{l}\text { Barren mares } \\
\text { pregnancy }(\%)\end{array}$} \\
\hline T1 - control & 41 & 36,6 \\
T2 - plasma & 34 & 50,0 \\
T3 - plasma + leukocytes & 37 & 64,8 \\
T4 - plasma + antibiotics & 18 & 33,3 \\
\hline
\end{tabular}

$\chi^{2}=7,962 ; p=0,047$
Separation of homologous plasma: For each mare, $500 \mathrm{ml}$ blood with $\mathrm{Na}$-heparin $(10 \mathrm{JU} / \mathrm{ml}$ of blood) were collected at the first or second day of estrus. The collected blood was placed in a refrigerator $\left(5^{\circ} \mathrm{C}\right)$ for 2 hours to allow sedimentation and plasma separation. Plasma was split into $120 \mathrm{ml}$ aliquots and frozen $\left(-20^{\circ} \mathrm{C}\right)$ until use. Thawing was performed in a $38^{\circ} \mathrm{C}$ waterbath.

Separation of homologous plasma with leukocytes: $270 \mathrm{ml}$ of heparinized blood $(10 \mathrm{JU} / \mathrm{ml})$ were collected one hour before infusion. After plasma separation, $100 \mathrm{ml}$ of a $6 \%$ dextrose solution were added. Leukocytes floatation occurred after 30 minutes (Castilho, 1994). Enriched plasma (>5000 leukocytes $/ \mathrm{mm}^{3}$ ) was then separated using a siphon and used immediately.

The treatments were given 13 to 36 hours after mating. If no ovulation was detected within $48 \mathrm{~h}$ of first breeding, a second service took place and treatment procedures were repeated.

Pregnancy diagnosis was done by ultrasonography 14 days after ovulation. Twin pregnancies were manually reduced. Pregnancies were followed up by weekly examinations and early embryonic losses detected until 40 days after ovulation.

\section{Statistical analysis}

Data were analyzed by means of a general linear model system (SAS Institute, 1995). The model included the main variables of mare status, age, treatment, farm, corporal condition, endometritis history, biopsy score, perineal conformation, period between breeding and treatment, and the dependent variable of pregnancy rate. Specific interactions between factors were not found to be significant and were excluded from the final model. Pregnancy results were analyzed using the Chi-square test.

\section{Results}

Early pregnancy rates for maiden mares $(n=60)$ under different treatments were as follows: $58,8 \%$ for control group (T1, $n=17$ ); $68,4 \%$ for T2 (plasma, $n=19$ ); $71,4 \%$ for T3 (plasma + leukocytes, $n=14$ ) and $70,0 \%$ for T4 (plasma + antibiotics, $n=10)$, they did not differ significantly $(p=0,876)$. The lactating mare group $(\mathrm{n}=204)$ did not show any difference $(p=0,815)$ in pregnancy rate: $56,2 \%$ for T1 (control, $\mathrm{n}=64$ ); $52,7 \%$ for T2 (plasma, $\mathrm{n}=55$ ); $61,8 \%$ for T3 (plasma + leukocytes, $n=55$ ) and 56,6\% for T4 (plasma + antibiotics, $n=30$ ).

In the barren mare group $(n=130), 22,8 \%$ had not foaled for more than two years. According to histopathologic examination, $14,0 \%$ showed endometrium grade $1 ; 33,3 \%$ grade $2 \mathrm{a} ; 43,9 \%$ grade $2 \mathrm{~b} ; 8,8 \%$ grade 3 . The early pregnancy rates obtained in barren mares are shown in Table 1. Table 1 shows that barren mares submitted to T3 (plasma + leukocytes) obtained better early pregnancy rates per cycle $(p=0,047)$ than those submitted to T1, T2 and T4.

The time of period between breeding and treatment ranged from 13 to 36 hours. No differences $(p>0,05)$ were observed between periods. 
Treatments did not significantly affect $(p>0,05)$ early embryonic loss rates in maiden $(8,7 \%)$, barren $(12,9 \%)$ and lactating mares $(8,6 \%)$.

\section{Discussion}

Pregnancy rates obtained in this study are similar to those of Woods et al. (1987) concerning to maiden and lactating mares, and to those of Pascoe (1995) concerning to barren mares.

Results show that postbreeding treatment was effective only in barren mares. A comparison between pregnancy rates of maiden and lactating mares with the control group did not show any advantage in using postbreeding treatments. These mares probably have an effective uterine defense mechanism and no postbreeding therapy is needed, except for isolated cases.

Barren mares treated with plasma plus leukocytes had higher pregnancy rates than barren mares receiving only plasma infusion. However, these two treatments were significantly superior to the remaining ones (control and plasma plus antibiotics). The barren mare group included mostly mares with previous infertility and, consequently, those susceptible to endometritis.

It is not clear why leukocytes in mares susceptible to endometritis have a diminished or inhibited phagocytic activity. Liu et al. (1986) observed that the motility of neutrophils obtained from uteri of susceptible mares remains functional until 12 hours following an induced inflammatory process, when they become nonfunctional. This does not happen to neutrophils obtained from uteri of healthy mares (Liu et al., 1985). Troedsson et al. (1993a) concluded that phagocytosis, but not chemotaxis, of uterine polymorphonuclear neutrophils is impaired in mares susceptible to bacterial endometritis as a result of a negative effect of uterine secretions on phagocytosis and not due to any dysfunction of the cells themselves. Regardless of the cause of the dysfunction, it has been shown that blood-polymorphonuclears in both susceptible and resistant mares are fully functional (Liu et al., 1985; Watson, 1987). Based on these findings, an infusion with leukocytes obtained from the blood was chosen for this study, in order to avoid possible negative effects from exposure to the endometrium. This technique allows to obtain more than $90 \%$ viable neutrophils, whose phagocytic ability is maintained up to 6 hours. This was attested by flow cytometry, evaluating intracellular oxygen metabolism and bacterial ingestion/digestion (Castitho, 1997). This treatment proved to be more effective in barren mares than in others in which it was tested.

The better pregnancy rates are probably directly related to a synergistic effect of the two components of the treatment. First, the homologous plasma infusion added opsonizing factors (complement factors and immunoglobulins) to the uterine lumen (Asbury, 1984) promoting uterine contraction and elimination of contaminating material; second, the addition of fresh blood neutrophils allowed optimal phagocytosis, possibly enhanced by the former step. This interaction of physical, humoral and cellular factors includes all major defense mechanisms against uterine infections. In contrast to the observations by Pascoe (1995), who used a combination of penicillin and neomycin, in this study the use of plasma with antibiotics (penicillin and streptomycin) did not improve pregnancy rates.

It was concluded that the postbreeding intrauterine infusion of plasma and leukocytes improves pregnancy rates per cycle in barren mares.

\section{References}

Allen, W. E. and Pycock, J.F. (1988): Clinical accumulation of uterine fluid in mares with lowered resistance to endometritis. The Veterinary Record 122, 489-490.

Asbury, A.C. (1984): Uterine defense mechanisms in the mare: the use of intrauterine plasma in the management of endometritis. Theriogenology 21, 387-393.

Asbury, A.C. (1986): Endometritis in the mare. In: Current therapy in theriogenology. Ed. Morrow, D.A., Saunders, Philadelphia. 718-722.

Asbury, A. C., Schultz, K. T., Klesius, P.N., Foster, G.W. and Washburn, S.N. (1982): Factors affecting phagocytosis of bacteria by neutrophils in the mare's uterus. J. Reprod. Fert. Suppl. 32, 151-159.

Ball, B. A., Little, T. V., Hillman, R. B. and Woods, G. L. (1986): Pregnancy rates at days 2 and 14 and estimated embryonic loss rates prior to day 14 in normal and subfertile mares. Theriogenology 26, $611-619$.

Dimmock, W.W. (1939): Equine breeding hygiene. J.Am. Vet. Assoc 94, 469-478.

Castiho, L. F. F. (1994): Endometrite na égua: plasma homólogo acrescido de leucócitos como forma de tratamento. Dissertation, Faculdade de Veterinária da Universidade Federal do Rio Grande do Sul, Porto Alegre, Brazil.

Castilho, L.F.F., Malschitzky, E., Gregory, R. M. and Mattos, R. C. (1994): Treatment of endometritis in the mare with homologous plasma containing neutrophils. Proceedings 6 . International Symposium on Equine Reproduction, Caxambu, Brazil, 135-136.

Castilho, L.F.F. (1997): Personal communication

Cheung, A.T., Liu, I. K. M., Walsh, E. M. and Miller, M. E. (1985): Phagocytic and killing capacities of uterine-derived polymorphonuclear leukocytes from mare resistant and susceptible to chronic endometritis. Am. J. Vet. Res. 46 (9), 1938-1940.

Evans, M. J., Hamer, J.M., Ganson, L.M. Graham, C. S., Asbury, A.C. and Irvine, C. G. H. (1986): Clearance of bacteria and nonantigenic markers following intra-uterine inoculation into maiden mares: effect of steroid hormone environment. Theriogenology 26 , $37-50$.

Hughes, J.P. and Loy, R. G. (1975): Investigation on the effect of intrauterine inoculation of Streptococcus zooepidernicus in the mare. Proc. Am. Assoc. Equine Pract., 289-292.

Kenney, R. M. and Doig, P. A. (1986): Equine endometrial biopsy. In: Current therapy in theriogenology. Ed. Morrow, D. A., Saunders, Philadelphia.723-729.

Kenney, R.M. and Ganjam, V.K. (1975): Selected pathological changes of the mare uterus and ovary. J. Reprod. Fert. Suppl. 23, 335-339.

Leblanc, M.M., Asbury, A. C. and Lyle, S. K. (1989): Uterine clearance mechanisms during the early postovulatory period in mares. Am. J. Vet. Res. 50 (6), 864-867.

LeBlanc, M. M. Neuwirth, L., Asbury, A. C., Tran, T. Mauragis, D. and Klapstein, E. (1994): Scintigraphic measurements of uterine clearance in normal mares and mares with recurrent endometritis. Equine Vet. J. 26 (2), 109-113.

LeBlanc, M.M., Johnson, R. D., Calderwood Mays, M. B. and Valderrama, C. (1995): Lymphatic clearance of india ink in reproductively normal mares and mares susceptible to endometritis. Biol. Reprod. Mono. 1, 501-506. 
Liu, I. K. M., Cheung, A. T.W., Walsh, E.M. and Ayin, S. (1986): The functional competence of uterine-derived polymorphonuclear neutrophils (PMN) from mares resistant and susceptible to chronic uterine infection: a sequential migration analysis. Biol Reprod. 35 , $1168-1174$

Liu, I. K. M., Cheung, A.T.W., Walsh, E. M., Miller, M. E. and Lindemberg, P.M. (1985): Comparison of peripheral blood and uterine derived polymorphonuclear leukocytes from mares resistant and susceptible to chronic endometritis: chemotatic and cell elastimetry analysis. Am. J. Vet. Res. 46, 917-920.

Mattos, R. C., Mattos, A. L. G., Günzel, A-R and Klug, E. (1984): Bakteriologische und zytologische Untersuchung von Uterusabstriche beim Pferd. Prakt. Tierarzt 65, 809-814.

Pascoe, D. R. (1995): Effect of adding autologous plasma to an intrauterine antibiotic therapy after breeding on pregnancy rates in mares. Biol. Reprod. Mono 1, 539-543.

Pascoe, D. R., Liu, I. K. M. Spensley, M. S. and Hughes, J. P. (1985): Effect of endometrial pathology on the success of non-surgical embryo transfer. Equine Vet. J. Suppl. 3, 108-110.

Squires, E.L., Imel, K. J., luliano, M.F. and Shiedeler, R. K. (1982) Factors affecting reproductive efficiency in an equine embryo transfer program. J. Reprod. Fert. Suppl. 32, 409-414.

Troedsson, M.H.T. and Liu, I.K.M. (1991): Uterine clearance of nonantigenic markers $\left({ }^{51} \mathrm{Cr}\right)$ in response to a bacterial challenge in mares potentially susceptible and resistant to chronic uterine infections. J. Reprod. Fert. Suppl. 44, 283-288.

Troedsson, M.H.T. and LiU, I.K.M. (1992): Measurement of total volume and protein concentration of uterine secretion after intrauterine inoculation of bacteria in mares that were either resistant or susceptible to chronic uterine infection. Am. J. Vet. Res. 53 (9), $1641-1644$

Troedsson, M. H. T. LiU, I. K. M. and Thurmond, M. (1993a): Function of uterine and blood-derived polymorphonuclear neutrophils in mares susceptible and resistant to chronic uterine infection: phagocytosis and chemotaxis. Biol. Reprod. 49, 507-514.

Troedsson, M. H. T., Liu, I. K. M. and Thurmond, M. (1993b): Immunoglobulin ( $\mathrm{IgG}$ and $\mathrm{IgA}$ ) and complement ( $\mathrm{C}_{3}$ ) concentrations in uterine secretions following an intrauterine challenge of Streptococcus zooepidemicus in mares susceptible and resistant to chronic uter ine infection. Biol. Reprod. 49, 502-506.

Troedsson, M. H. T., Scott, M. A. and Liu, I. K. M. (1995): Comparative treatment of mares susceptible to chronic uterine infection. Am. J. Vet. Res. 56 (4), 468-472

Watson, E. D. (1987): Uterine cellular and humoral defense mechanisms in mares susceptible and resistant to persistent endometritis. Vet Imunol. Imunopathol. 16, 107-121.

Watson, E. D. (1988): Uterine defense mechanisms in mares resistant and susceptible to persistent endometritis: a review. Equine Vet. J. 20 (6), 397-400

Woods, G. L., Baker, C. B., Baldwin, J. L., Ball, B. A., Bilinski, J., Cooper, W.L., Ley, W. B., Mank, E. C. and Erb, H.N. (1987): Early pregnancy loss in broodmares, J. Reprod. Fert. Suppl. 35, $455-459$

\section{Prof. Ricardo Costa Mattos}

Reprolab, Departamento de Medicina Animal Faculdade de Veterinária

Universidade Federal do Rio Grande do Sul

P.O. Box 15094, 91501-970 Porto Alegre, Brazil

Tel/Fax: 0055-51-3360512

email: mattosrc@vortex.ufrgs.br

\title{
2nd Maastricht International Congress on Equine Medicine
}

\author{
29. 11.1997 \\ Simultanübersetzung: Deutsch - Holländisch - Englisch
}

\section{Tagungsort:}

Maastricht Exhibition Congress Center; MECC

Forum 100, Maastricht, Niederlande

\section{Tagungsgebühren:}

DM 270,- bei Überweisung bis zum 31. 10 . 1997

DM 320,- nach dem 1. 11. 1997

Alle Preise verstehen sich incl. MwSt.

Studenten zahlen jeweils die Hälfte.

Überweisungen: M.I.C.E.M. Sparkasse Geldern Kontonummer 394882 (BLZ 32051370 )

Die Tagungsgebühr beinhaltet Mittagessen, Kaffeepausen, happy hour" nach der Podiumsdiskussion und Proceedings sowie freien Tageseintritt für das Reitturnier J.I.M - Jumping Indoor Maastricht und die Ausstellung von M.I.C.E.M.

\section{Abendprogramm:}

J.I.M. - Jumping Indoor Mastricht: Eintritt DM 45,Bitte gemeinsam mit der Tagungsgebühr auf $\mathrm{o}$. a. Konto überweisen.

\section{Anmeldungen/Info: \\ Tierklinik Kerken \\ Slümer Straße 5-6 \\ 47669 Wachtendonk \\ Telefon (02836) 91410 \\ Fax (0 2836) 85289}

\section{Hotelreservierung:}

Für Reservierungen zu Sonderpreisen kontaktieren

Sie bitte den MECC Hotelservice:

Telefon (00 31) 433838383

Fax (00 31) 433838300 